\title{
Financial Performance, Ratio Analysis and Evaluation of Agricultural Bank of China
}

\author{
Abdul Rehman ${ }^{1}$, Luan Jingdong ${ }^{1}$, Yuneng Du ${ }^{1}$, Rafia Khatoon ${ }^{2}$, Sehran Khan Nisar ${ }^{3}$, \\ Liting Zhang ${ }^{1}$, Toufeeq Shahzad ${ }^{4}$ \\ ${ }^{1}$ College of Economics and Management, Anhui Agricultural University, China \\ ${ }^{2}$ Business Administration (MBA), The University of Azad Jammu \& Kashmir \\ ${ }^{3}$ School of Public Affairs, University of Science \& Technology, China \\ ${ }^{4}$ School of Plant Protection, Anhui Agricultural University, China
}

Email address:

abdulrehman@ahau.edu.cn (A. Rehman), luanjingdong@ahau.edu.cn (Luan Jingdong)

\section{To cite this article:}

Abdul Rehman, Luan Jingdong, Yuneng Du, Rafia Khatoon, Sehran Khan Nisar, Liting Zhang, Toufeeq Shahzad. Financial Performance, Ratio Analysis and Evaluation of Agricultural Bank of China. International Journal of Economic Behavior and Organization.

Vol. 3, No. 5, 2015, pp. 69-73. doi: 10.11648/j.ijebo.20150305.11

\begin{abstract}
This paper formulates and investigates the financial performance, ratio analysis of Agricultural Bank of China banking sector for the period 2010-2014. The study concluded that financial performance of any firm or bank can be calculated with the help of financial ratios. Financial ratio plays an important role to check the condition of any bank or company either is in profit or loss.
\end{abstract}

Keywords: Agricultural Bank of China, Financial Performance, Financial Ratio Analysis, Investment Banking, Banking Management and Stock Exchange

\section{Introduction of ABC}

The Agricultural Bank of China (ABC) established in 1951. Later in 1970s Agricultural Bank of China specialized and wholly state-owned as a commercial Bank and subsequently controlled by Commercial Bank. In January 2009 the bank was restructured into a joint stock limited company, later bank was listed at the Stock Exchange of Shanghai and Hong Kong Stock Exchange in July 2010. Agricultural Bank of China is one of the major banks who provide integrated financial services, also capitalizing the urban areas of the country. It provides diversified services and strives to expand into international market to become first class bank. Due to good business portfolio and advanced information technology, bank provides various types of banking. Agricultural Bank of China provides investment banking, fund banking management, financial leasing and life insurance services.

The bank has total assets of RMB 13,244,342 million, deposit of RMB 10,862,935 million and loans of RMB $6,433,399$ million at the end of 2012. Bank capital and nonperforming loan ratio are $12.61 \%$ and $1.33 \%$ respectively. In 2012 bank achieved a net profit of RMB 145,131 million.
Agricultural Bank of China has 23,472 domestic branches which includes Head office. Bank has four overseas branches and above five overseas representative offices. It has nine domestic subsidiaries and three overseas subsidiaries. The bank ranked No. 84 in Fortune's Global 500, ranked also at No.5 Top 1000 World Banks due to profit before tax in 2011.

\section{Literature Review of Ratio Analysis}

Financial ratios are widely used for the purposes to calculate the profitability and financial condition of a bank or firm. The firm involves many interested parties, like the owners, management, personnel, customers, suppliers, competitors and academics, each having their views in applying financial statement analysis in their evaluations. Practitioners use financial ratios, for instance, to forecast the future success of companies, while the researchers' main interest has been to develop models exploiting these ratios.

Barnes (1982) shows how the non-normality of financial ratios can result from the underlying relationships of the constituents of the financial ratios. He is thus able to tie in the ratio format aspects with the distributional properties of financial ratios (to be discussed later in this review). In the 
discussion on Barnes's paper (Horrigan, 1983, Barnes, 1983), Horrigan puts forward that financial ratio research should be more interested in the role of the financial ratios themselves than in "the nature of the ratios' components or to the ratios' incidental role as data size deflators".

Justin (1924) argued that the method of gathering industry data and calculates averages were called "Scientific ratio analysis". The word "scientific" in this title was not entirely correct because no evidence had been found that the hypothesis formulation and hypothesis testing actually carried out.

Horrigan (1968) says ratios analysis has come into existence since early ages and the main reason of the development of ratio analysis was its use in the analysis of the properties of ratios in 300 B.C. in recent time it is used as a standard tool for the analysis of financial statement. In nineteenth century main reasons of using ratio analysis are power of financial institutions and shifting of management to professional managers. Ratio analysis used for two purposes that are credit and managerial. In managerial approach profitability and in credit approach capacity of firm to pay debts is the main point of focus. Generally, ratio analysis is used credit analysis.

Technically, financial ratios can be divided into several, sometimes overlapping categories. A financial ratio is of the form $\mathrm{X} / \mathrm{Y}$, where $\mathrm{X}$ and $\mathrm{Y}$ are figures derived from the financial statements or other sources of financial information. One way of categorizing the ratios is on the basis where $\mathrm{X}$ and Y come from (see Foster, 1978, pp. 36-37, and Salmi, Virtanen and Yli-Olli, 1990, pp. 10-11). In traditional financial ratio analysis both the $\mathrm{X}$ and the $\mathrm{Y}$ are based on financial statements. If both or one of them comes from the income statement the ratio can be called dynamic while if both come from the balance sheet it can be called static (see ibid.).

Bird and McHugh (1977) adopt an efficient Shapiro-Wilk small-sample test for the normality of financial ratios for an Australian sample of five ratios over six years. Like Deakin they find in their independent study that normality is transient across financial ratios and time.

Aho (1980) includes also cash-flow based profitability ratios in a factorization study for 24 financial ratios of 57 Finnish firms in 1967-1976. His financial characteristic factors become financial structure, profitability, liquidity, working capital turnover and financial opportunities for investments. Gombola and Ketz (1983) include cash-flow based (adjusted for all accruals and deferrals) financial ratios in their factorization of 40 financial ratios for a sample of 119 Compustat firms for 1962-80. Contrary to the earlier studies, the cash-flow based financial ratios load on a distinct factor. The results are not sensitive to using historical costs vs general price-level adjusted data.

Libby (1975) reduces an original 14-ratio set to five financial factors by a principal component analysis in connection with a bankruptcy study. Another example is Richardson and Davidson (1984). Hutchinson, Meric and Meric (1988) also classify ratios with principal component analysis in a study attempting to identify small firms which have achieved quotation on the UK Unlisted Securities
Market. Martikainen (1993) classifies financial ratios and tests their stability with transformation analysis in a study on identifying the key factors which determine stock returns.

There was rapid expansion of financial knowledge in nineteenth century and to study this rapidly expanding knowledge analyst first compared similar items then moved further and compared current assets and liabilities as well with other ratios. In that period current ratio was the most significant ratio among all other available ratios. To analyze the operating results DuPont analysis is also used. The result divided into three parts and then compared with other companies to point out the problem and strong areas of business.

Bliss (1923) says basic relationship within the business is indicated by the ratios and developed complete model based on the ratios. The purpose model was not mature but inspired others to start working on this theory.

Gilman (1925) has following concerns on ratio analysis (1) ratios are bond with time and changed as time passed so cannot be interpreted (2) ratios are not natural measure for judging the performance companies manipulated them (3) ratios easily affect the mind of viewers and hide the actual position and (4) ratios swing widely that also affect the dependability. Foulke (1931) create and promoted own set of financial ratios successfully. This set of financial ratios was printed and promptly known as important and prominent group of ratios.

Fitzpatrick (1932) with the help of thirteen different type of ratios analysis 120 failed firms and found that three out of thirteen ratios predict the failure of firms with precise accuracy while other ratios also shown some prediction power.

Rasmer and foster (1931) used eleven ratios to examine that the successful firms has higher ratios than unsuccessful firms. Although this study was immature but immaturity was ignored by considering the vital contribution this study has in the evaluation of usefulness of ratios. Security and exchange commission of America was formed in 1934. This also expands the flow and number of financial statements and with the help of this peripheral factor importance of ratio analysis further enhanced and realized.

Moore and Atkinson (1961) point out the relationship between capacity to pay and financial ratios and shows results of ratio analysis influence the borrowing ability of firms. Sorter and Becker (1964) examined the relationship between psychological model and corporate personality of financial ratios and find out that long-established corporation maintain greater liquidity and solvency ratios.

Beaver (1967) also examined the prediction power of ratio analysis and point out ratios ability to predict failure as early as five years before the collapsed. Statistical technique used in the study was more powerful than earlier studies and fund statement data was used to calculate ratio. This study set the foundation for future research on ratio analysis. Gombola and Ketz (1983) found that the fund and income statement are produced for different purpose and profitability ratios did not has the information that cash flow ratios provide. In other words both ratios gave important as well as different information from one and other. 


\section{Profitability, Performance and Ratio Analysis of Agricultural Bank of China}

Agricultural Bank of China (ABC) total assets and liabilities for the period 2010-2014 are shown in the fig 1 .

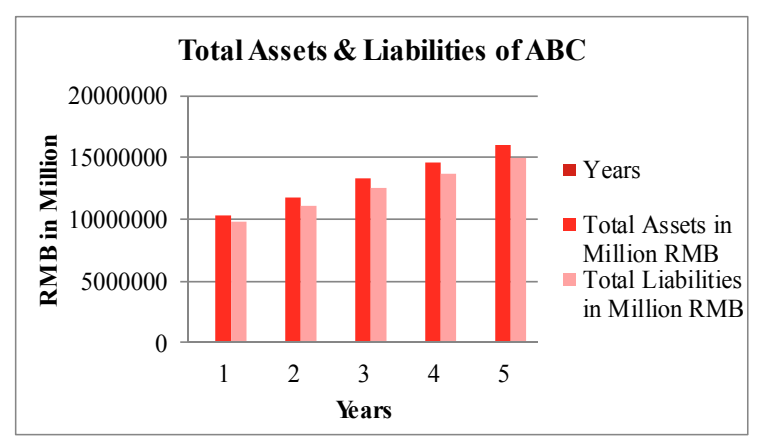

Data Source: Agricultural Bank of China Annual Reports 2010-2014

Fig. 1. Total Assets and Liabilities of ABC.

In 2010 Agricultural Bank of china (ABC) total assets was $10,337,406$ million RMB next three years it increased and in 2014 total assets reached to $15,974,152$ million RMB. Similarly, total liabilities in 2010 were $9,795,170$ million RMB and increased every year reached 14,941,533 million RMB in 2014.

Financial ratio analysis of Agricultural Bank of China is shown in the fig. 2-6 from 2010-2014.

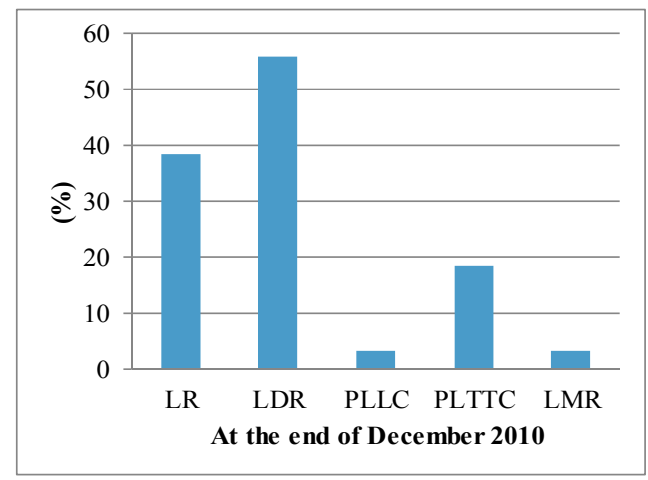

Fig. 2

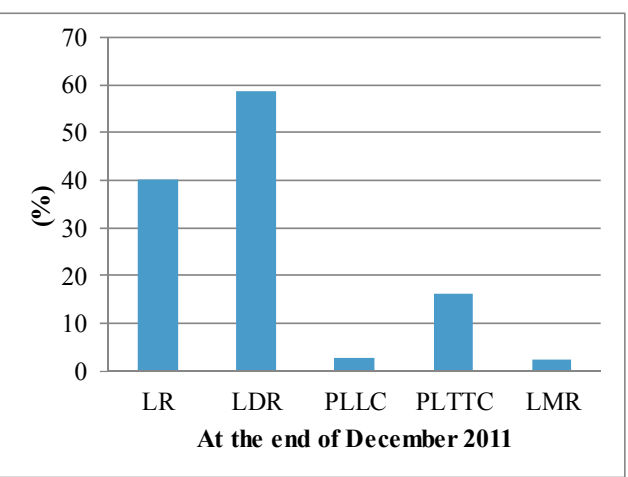

Fig. 3

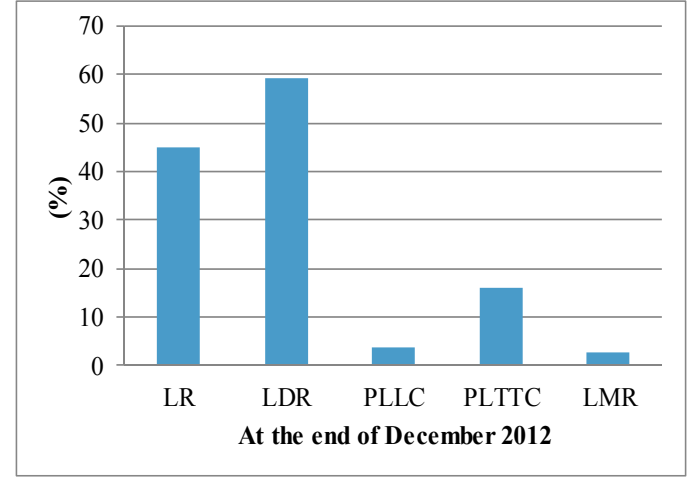

Fig. 4

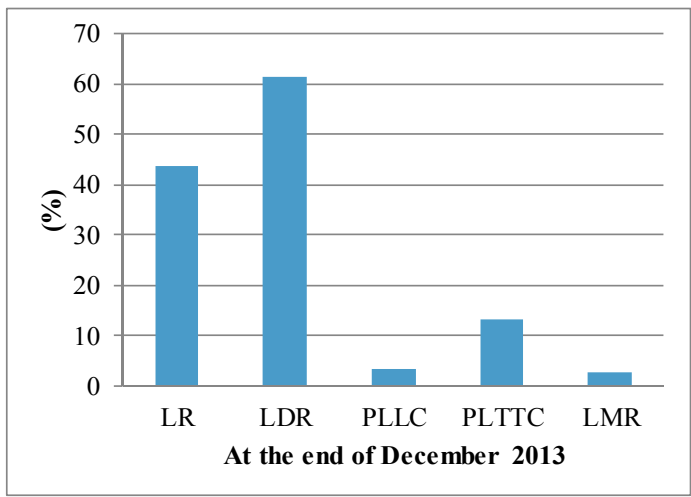

Fig. 5

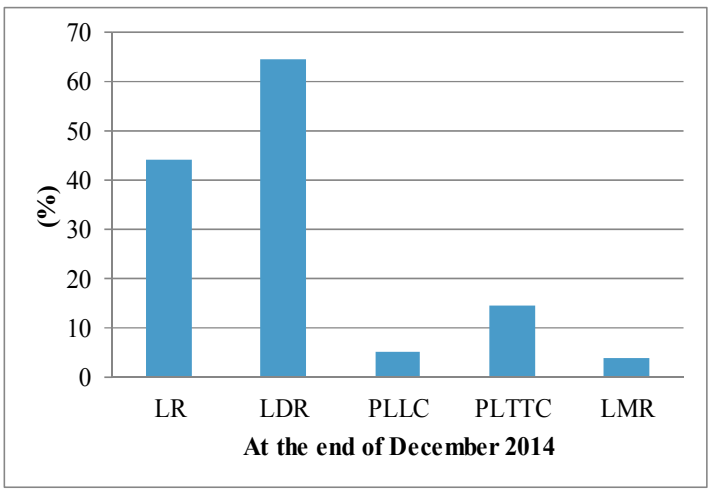

Fig. 6

Data Source: Agricultural Bank of China Annual Reports 2010-2014

Fig. 2-6. Ratio Analysis of $A B C$.

In 2010 Agricultural Bank of China liquidity ratio (LR) was $38.36 \%$ and it increased every year $44.02 \%$ in 2014 . Loan-to-deposit ratio (LDR) was $55.77 \%$ in 2010 and increased in 2011, 2012, 2013 and 64.61\% was in 2014. Percentage of loans to the largest single customer (PLLC) in 2010 was $3.18 \%$ and it also increased to $5.23 \%$ in 2014 . Percentage of loans to top ten customers (PLTTC) was $18.45 \%$ in 2010 and it decreased every year $14.43 \%$ in 2014 . Loan migration ratio Normal (LMR) was $3.10 \%$ in 2010 and increased $3.60 \%$ in 2014 .

Agricultural Bank of China Profitability in \% from 20102014 are shown in fig. 7-11. 


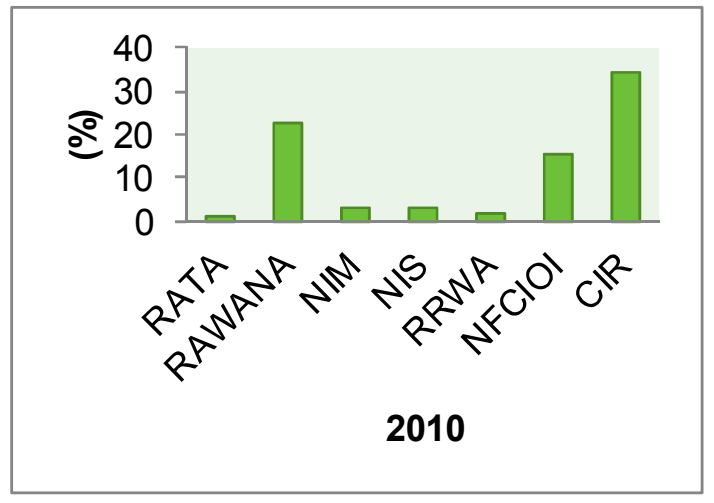

Fig. 7

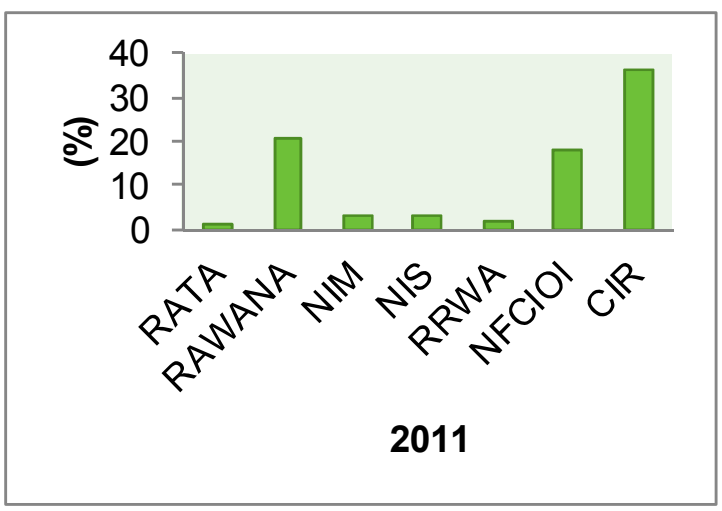

Fig. 8

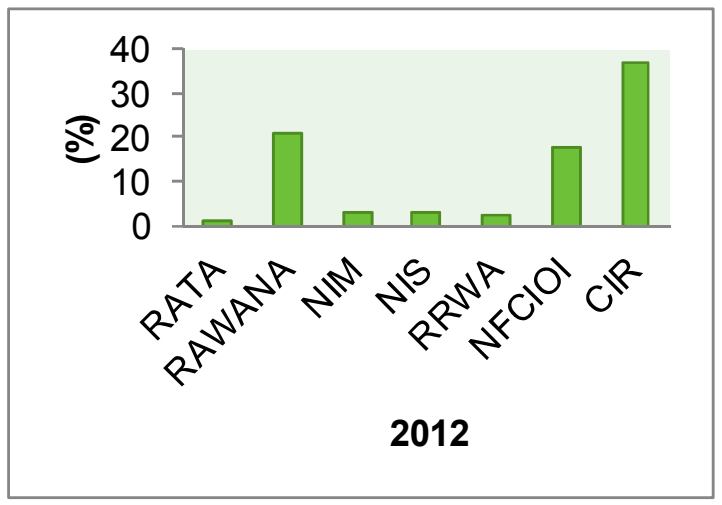

Fig. 9

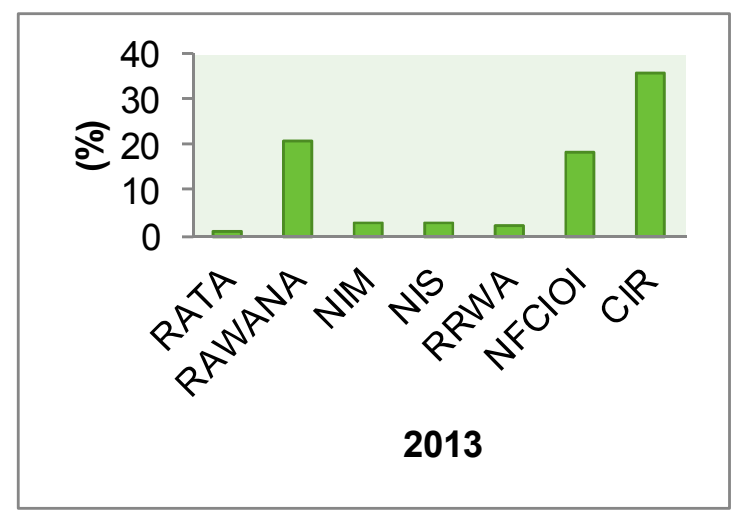

Fig. 10

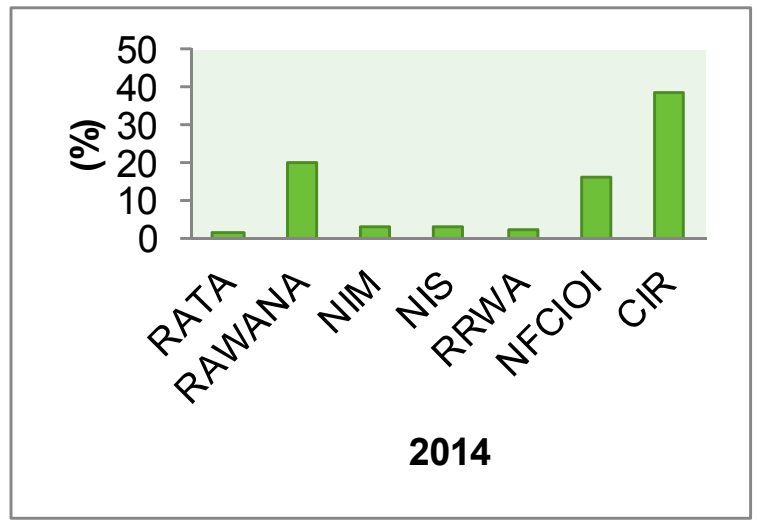

Fig. 11

Data Source: Agricultural Bank of China Annual Reports 2010-2014

Fig. 7-11. Profitability in \% from 2010-2014 of ABC.

In fig. 7-11 Return on average total assets (RATA) 2010 was $0.99 \%$ and increased every year reached $1.18 \%$ in 2014 . Return on weighted average net assets (RAWANA) was $22.49 \%$ and 2014 it reached to $19.57 \%$. Net interest margin (NIM) in 2010 was $2.92 \%$ and 2014 it reached to $2.57 \%$. Net interest spread (NIS) in 2010 was $2.76 \%$ and it reached to $2.50 \%$ in 2014 . Return on risk-weighted assets (RRWA) in 2010 was $1.65 \%$ and it increased to 1.76 in 2014. Net fee and commission income to operating income (NFCIOI) was $15.29 \%$ and reached to $15.78 \%$ in 2014 . Cost-to-income ratio (CIR) was $34.56 \%$ in 2010 and increased to $38.59 \%$ in 2014.

\section{Conclusion}

Financial performance of any firm or bank can be calculated with the help of financial ratios. Financial ratio plays an important role to check the condition of any bank or company either is in profit or loss. By using ratios companies can determine financial strength or weaknesses as well as opportunities in the market or industry. Ratios can provide the actual picture of the firm's financial position. Financial ratios assist analysts to acquired insight knowledge of firm's financial situation. Data from different financial statements has used to calculate the ratios. Financial ratios can tell the investors future performance of firms by looking past trends. Ratios helped management to act more logically and made financial decision on more knowledge and less risky. At the end of 2014, Agricultural Bank of China had total assets of RMB 15,974,152 million, loans and advances to customers of RMB 8,098,067 million and deposits of RMB 12,533,397 million. Bank capital adequacy ratio was $12.82 \%$. The Bank achieved a net profit of RMB 179,510 million in 2014.

\section{Abbreviations}

LR: Liquidity ratio (\%)

LDR: Loan-to-deposit ratio (\%)

PLLC: Percentage of loans to the largest single customer (\%)

PLTTC: Percentage of loans to top ten customers (\%) 
LMR: Loan migration ratio (\%) Normal

RATA: Return on average total assets

RAWANA: Return on weighted average net assets

NIM: Net interest margin

NIS: Net interest spread

RRWA: Return on risk-weighted assets

NFCIOI: Net fee and commission income to operating income

CIR: Cost-to-income ratio

\section{References}

[1] Horrigan, J.O. (1983), "Methodological implications of nonnormally distributed financial ratios: a comment", Journal of Business Finance and Accounting 10/4, 683-689.

[2] Horrigan, J.O. (1965), "Some empirical bases of financial ratio analysis", Accounting Review, July 1965, 558-568.

[3] Salmi, T., Virtanen, I., and Yli-Olli, P. (1990), "On the classification of financial ratios. A factor and transformation analysis of accrual, cash flow, and market-based ratios", Acta Wasaensia, no 25. Also published on the World Wide Web as http://www.uwasa.fi/ ts/sera/sera.html

[4] Bird, R.G., and McHugh A.J. (1977), "Financial ratios - an empirical study", Journal of Business Finance and Accounting 4/1, 29-45.
[5] Aho, T. (1980), "Empirical classification of financial ratios", Management Science in Finland 1980 Proceedings, ed. C. Carlsson.

[6] Gombola, M.J., and Ketz, J.E. (1983), "A note on cash flow and classification patterns of financial ratios", Accounting Review 63/1, 105-114.

[7] Libby, R. (1975), "Accounting ratios and the prediction of failure: some behavioral evidence", Journal of Accounting Research 13/1, 150-161.

[8] Richardson, F.M., and Davidson, L.F. (1984), "On linear discrimination with accounting ratios", Journal of Business Finance and Accounting 11/4, 511-525.

[9] Hutchinson, P., Meric, I., and Meric, G. (1988), "The financial characteristics of small firms which achieve quotation on the UK unlisted securities market", Journal of Business Finance and Accounting 15/1, 9-19.

[10] Martikainen, T. (1993), "Stock returns and classification pattern of firm-specific financial variables: empirical evidence with Finnish data", Journal of Business Finance and Accounting 20/4, 537-557.

[11] Beaver, W. (1977), "Financial Statement Analysis", Handbook of Modern Accounting, eds Davidson, S. and Weil, R., 2nd ed. McGraw-Hill.

[12] Agricultural Bank of China (ABC) annual Reports 2010-2014. 